\title{
Non-cardiogenic pulmonary oedema caused by iodine contrast medium
}

\author{
Genta Nagao, Katsunori Masaki 다 , Ichiro Kawada, Koichi Fukunaga
}

Division of Pulmonary Medicine, Department of Medicine, Keio University School of Medicine, Shinjukuku, Tokyo, Japan

\section{Correspondence to Dr Katsunori Masaki; masakik@keio.jp}

Accepted 10 November 2020

\section{DESCRIPTION}

A 44-year-old woman underwent contrast-enhanced CT with iopamidol because of a suspected sinusitis. After $10 \mathrm{~min}$, she developed dyspnoea and nausea. Intravenous administration of hydrocortisone $500 \mathrm{mg}$ and metoclopramide $10 \mathrm{mg}$ did not improve her symptoms. One hour later, her percutaneous oxygen saturation $\left(\mathrm{SpO}_{2}\right)$ dropped to $80 \%$, and she was rushed to the emergency room and was given intravenous etilefrine $2 \mathrm{mg}$ and the second dose of intravenous hydrocortisone $500 \mathrm{mg}$. She did not have any history of cardiac disease, asthma or food/ drug allergies. Her vital signs were as follows: body temperature of $37.1^{\circ} \mathrm{C}$, pulse rate of 96 beats $/ \mathrm{min}$, blood pressure of $106 / 77 \mathrm{~mm} \mathrm{Hg}$ and $\mathrm{SpO}_{2}$ of $90 \%$ despite the administration of $10 \mathrm{~L} / \mathrm{min}$ oxygen via a reservoir mask. Chest examination revealed bilateral coarse crackles but no stridor. No skin rash noted. Chest X-ray and CT demonstrated bilateral diffuse infiltrates but no cardiac dilatation (figure 1). Laboratory tests showed a decreased total protein $(4.9 \mathrm{~g}$ / $\mathrm{dL})$ and albumin $(2.8 \mathrm{~g} / \mathrm{dL})$, suggesting increased vascular leakiness. Serum NT-proBNP (N-terminal-pro brain natriuretic peptide) was normal $(60 \mathrm{pg} / \mathrm{mL})$. Her troponin T was negative, and ST-T wave changes were not observed on her ECG. Her echocardiography showed normal left ventricular systolic function. Her white blood cell count was $20000 / \mu \mathrm{L}$, and C reactive protein was $0.12 \mathrm{mg} / \mathrm{dL}$. Streptococcus pneumoniae and Legionella pneumophila urinary antigen tests were negative. Only normal flora was cultured from her sputum sample. We diagnosed non-cardiogenic pulmonary oedema.

Intravenous famotidine $10 \mathrm{mg}$, chlorpheniramine $5 \mathrm{mg}$, hydroxyzine $25 \mathrm{mg}$ and twice intramuscular epinephrine were administrated for suspected anaphylactic shock, but her vital signs did not improve. Three hours later, we performed tracheal intubation with mechanical ventilation (fractional inspired oxygen 0.5 , pressure support (PS) $10 \mathrm{~cm}$

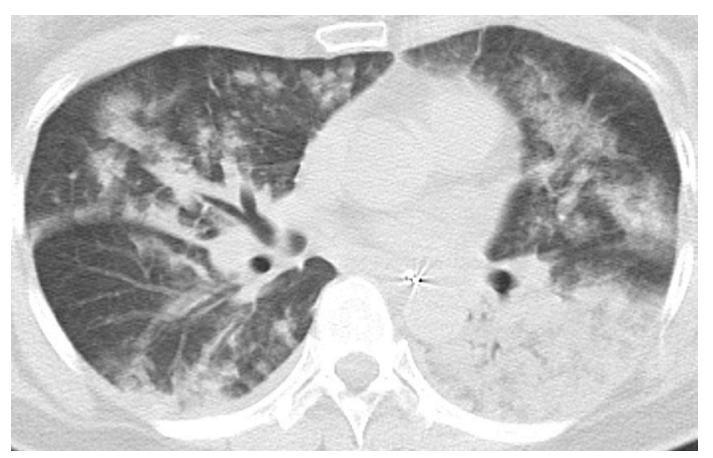

Figure 1 Chest CT showing diffuse bilateral infiltrates.

\section{Patient's perspective}

It never occurred to me that the sinus examination would cause respiratory failure requiring a ventilator.

\section{Learning points}

Physicians should consider rapid induction of positive pressure ventilation for non-cardiogenic pulmonary oedema that develops immediately after iodine contrast agent use.

- The effect of antihistamines, epinephrine and steroids is limited because pulmonary oedema is caused by damage to vascular endothelial cells due to chemical toxicity.

$\mathrm{H}_{2} \mathrm{O}$ and positive end-expiratory pressure (PEEP) $15 \mathrm{~cm} \mathrm{H} \mathrm{H}_{2} \mathrm{O}$ ). She was administrated intravenous levofloxacin (500 mg every 24 hours) for 5 days from admission. The next day, her chest infiltrates improved remarkably, and PS/PEEP were gradually reduced. She was extubated on the fourth day of hospitalisation, and thereafter oxygenation was administrated by cannula. She was discharged on the ninth day without any sequelae.

The frequency of pulmonary oedema caused by iodine contrast media has been reported to be $0.005 \%{ }^{1}$ and that with non-ionic iodine contrast media is unknown. Pulmonary oedema is thought to be caused by damage to vascular endothelial cells due to anaphylactoid reactions and/or chemical toxicity. ${ }^{2}$ Therefore, rapid induction of positive pressure ventilation is important. The effect of antihistamines, epinephrine and steroids is limited. ${ }^{34}$ The effect of diuretics is controversial because this reported sometimes exacerbates symptoms. ${ }^{5}$ Noncardiogenic pulmonary oedema should be considered for acute respiratory failure that develops immediately after iodine contrast agent use.

Acknowledgements We are deeply grateful to Keeya Sunata, Miyuki Nishie, Yuto Akiyama, Hiroki Kabata, Kenzo Soejima and staff of intensive care unit for their assistance and advices.

Contributors GN and KM wrote the draft. KM and IK discussed planning and interpreted data. KF conducted all the authors and design the report. All authors approved the final manuscript.

Funding The authors have not declared a specific grant for this research from any funding agency in the public, commercial or not-for-profit sectors.

Competing interests None declared.

Patient consent for publication Obtained. 
Images in...

Provenance and peer review Not commissioned; externally peer reviewed.

\section{ORCID iD}

Katsunori Masaki http://orcid.org/0000-0003-0909-9409

\section{REFERENCES}

1 Shehadi WH. Adverse reactions to intravascularly administered contrast media. A comprehensive study based on a prospective survey. Am J Roentgenol Radium Ther Nucl Med 1975;124:145-52.
2 Morcos SK. Review article: effects of radiographic contrast media on the lung. $\mathrm{Br} J$ Radiol 2003;76:290-5.

3 Kang $\mathrm{M}-\mathrm{H}$, Nah J-C, delayed A. A delayed, unusual non-cardiogenic pulmonary edema after intravascular administration of non-ionic, low osmolar radiocontrast media for coronary angiography. Korean Circ J 2013:43:500-3.

4 Pincet L, Lecca G. Acute pulmonary edema induced by non-ionic low-osmolar radiographic contrast media. Open Access Emerg Med 2018;10:75-9.

5 Paul RE, George G. Fatal non-cardiogenic pulmonary oedema after intravenous nonionic radiographic contrast. Lancet 2002;359:1037-8.

Copyright 2020 BMJ Publishing Group. All rights reserved. For permission to reuse any of this content visit

https://www.bmj.com/company/products-services/rights-and-licensing/permissions/

BMJ Case Report Fellows may re-use this article for personal use and teaching without any further permission.

Become a Fellow of BMJ Case Reports today and you can:

- Submit as many cases as you like

- Enjoy fast sympathetic peer review and rapid publication of accepted articles

- Access all the published articles

Re-use any of the published material for personal use and teaching without further permission

Customer Service

If you have any further queries about your subscription, please contact our customer services team on +44 (0) 2071111105 or via email at support@bmj.com.

Visit casereports.bmj.com for more articles like this and to become a Fellow 